\title{
Effects of environment and genotype for the expression of weight gain of Fayoumi and Sonali chicks
}

\author{
Miazi $\mathrm{OF}^{1 *}$, Miah $\mathrm{G}^{1}$, Uddin $\mathrm{MM}^{2}$, Hassan $\mathrm{MM}^{3}$ and $\mathrm{AhsanMF}^{4}$ \\ ${ }^{1}$ Department of Genetics and Animal Breeding, ${ }^{2}$ Department of Anatomy and Histology and ${ }^{3}$ Department of \\ Physiology Pharmacology and Biochemistry, Chittagong Veterinary and Animal Sciences University Khulshi, \\ Chittagong-4202 Bangladesh and ${ }^{4}$ Department of Zoology, Chittagong University.
}

[Received: 16 January 2011, Accepted: 01March 2011]

\begin{abstract}
Environmental as well as genotypic effect on weight gain is a normal phenomenon. The aim of the present study was to determine the environment and breed effect on weight gain. One observational cross-sectional study was done on the Fayoumi and Sonali chicks at Chittagong and Noakhali district from October 2005 to July 2006. A total of 48 farmers ( 24 from each Upazila) were selected randomly, who rear chicks under scavenging condition as well as had broody hens. Twelve eggs of each breed were supplied to each farmer. The chicks were hatched out by the farmers managed broody hens. Then the chicks were reared under scavenging system. The weight-gain of Fayoumi chicks after 8 weeks was higher $(226.0 \mathrm{gm})$ than Sonali $(170.7 \mathrm{gm})$ and it differed significantly $\left(\chi^{2}=7.71, \mathrm{df}=1, \mathrm{p}<0.01\right)$. The Fayoumi chicks of Chittagong site gained higher weight $(285.4 \mathrm{gm})$ than that of Noakhali $(171.1 \mathrm{gm})$. In case of Sonali chicks, the weight gain of day old to eight weeks aged showed the similar performance in both Districts. Chicks of both breeds gained better weight in Chittagong than Noakhali significantly (Fayoumi: $\chi^{2}=28.6, \mathrm{df}=1, \mathrm{p}<0.001$; Sonali: $\chi^{2}=10.01, \mathrm{df}=1, \mathrm{p}<0.01$ ). Weight gain and environmental adaptation of Fayoumi chicks were better than Sonali.
\end{abstract}

Key words: Environment, Fayoumi, genotype, Sonali, weight gain.

\section{INTRODUCTION}

Weight gain is an important trait of poultry which determines the size or weight of the birds. . Live weight depends on both environment and heredity ${ }^{[6]}$. During the first few weeks of the growth period, environmental influence is greater than heredity ${ }^{[5]}$. Temperature, light, diet, management and disease affect on weight gain ${ }^{[11]}$. The consequence of breed and environment interaction is that breeding operations and companies have to perform breeding selection for same environment as the bird has to produce ${ }^{[10]}$. Smallholder backyard chicken production is a subsistence activity, providing egg and meat for family consumption and to some extent, cash income ${ }^{[4]}$. Fayoumi, an ancient breed from the Egyptian City of Fayoumi for egg production, is well known poultry breed in Bangladesh. Adult males reach a weight of $2 \mathrm{~kg}$ and females $1.5 \mathrm{~kg}$, which produce 200 eggs per year ${ }^{[3]}$. Sonali breed is a cross breed, which had been produced from the cross of Rhode Island Red (RIR) cocks and Fayoumi hens. It has specially been advocated in terms of their higher egg production rate and better adaptability in rural situation ${ }^{[1]}$. So a study has been done with the objective of environment as well as genotype affect on weight gains of chicks.

\section{MATERIALS AND METTHODS}

An observational cross-sectional study was done on the Fayoumi and Sonali chicks at Chittagong and
Noakhali district from October 2005 to July 2006. A total of 48 farmers (24 from each Upazila) were selected randomly, who rear chicks under scavenging condition as well as had broody hens. Twelve eggs of each breed were supplied to each farmer. The chicks were hatched out by the farmers managed broody hens. Then the chicks were reared under scavenging system.

The area of Chittagong zone is more populated and it is located in the southern-east part of Bangladesh. Noakhali is the southern District of Bangladesh. It is area with totally plane land where cultivate several types of crops. The people of the area mainly cultivate rice, wheat, teal, mustered and several kinds of vegetables in their fields. Noakhali region is comparatively less populated than Chittagong region, which provide more scavenges area for the scavenging chicks. These chicks were scavenged in around the farmers' homesteads and meet a major part of their feed requirements in this way and require little additional feed. The farmers were provided feed to their chicken scattered for 2 to 3 or more times a day schedule and mainly given rice, broken rice, rice polish, wheat, etc. The body weight gain of chicks from day-old to eight weeks was weighed by using the balance and it was maintained weekly interval. The environmental effect on genotypes has been detected on the basis of different value of several parameters (like temperature, humidity and feeding system) into deferent environments with different ecological combination (like land setup and population). Feeding and 
management systems were also considered as environmental effect on genotypes.

Table 1: Temperature and humidity at Chittagong and Noakhali

\begin{tabular}{|c|c|c|c|c|c|c|}
\hline \multirow{3}{*}{$\begin{array}{l}\text { Location } \\
\text { Months } \\
\text { October/05 }\end{array}$} & \multicolumn{3}{|c|}{ Chittagong } & \multicolumn{3}{|c|}{ Noakhali } \\
\hline & \multicolumn{2}{|c|}{$\begin{array}{l}\text { Average } \\
\text { Temperature } \\
\left({ }^{\circ} \mathrm{C}\right)\end{array}$} & \multirow{2}{*}{$\begin{array}{l}\text { Relative } \\
\text { Humidit } \\
\mathrm{y}(\%) \\
52\end{array}$} & \multicolumn{2}{|c|}{$\begin{array}{l}\text { Average } \\
\text { Temperature } \\
\left({ }^{\circ} \mathrm{C}\right)\end{array}$} & \multirow{2}{*}{$\begin{array}{l}\text { Relative } \\
\text { Humidit } \\
\text { y (\%) } \\
80\end{array}$} \\
\hline & 24 & 31 & & 20 & 28 & \\
\hline November/05 & 19 & 28 & 46 & 15 & 24 & 72 \\
\hline December/05 & 15 & 26 & 39 & 13 & 25 & 78 \\
\hline January/06 & 12 & 25 & 32 & 10 & 23 & 73 \\
\hline February/06 & 16 & 28 & 34 & 14 & 26 & 75 \\
\hline
\end{tabular}

Source: Zone-Chittagong climatic station and Maijdi Court climatic station $^{[12]}$

\section{RESULTS}

\section{Genotype effect on weight-gain}

The overall comparison of weight-gain of Fayoumi and Sonali chicks have been revealed that the former gained better weight in all stages of development compared to the later.

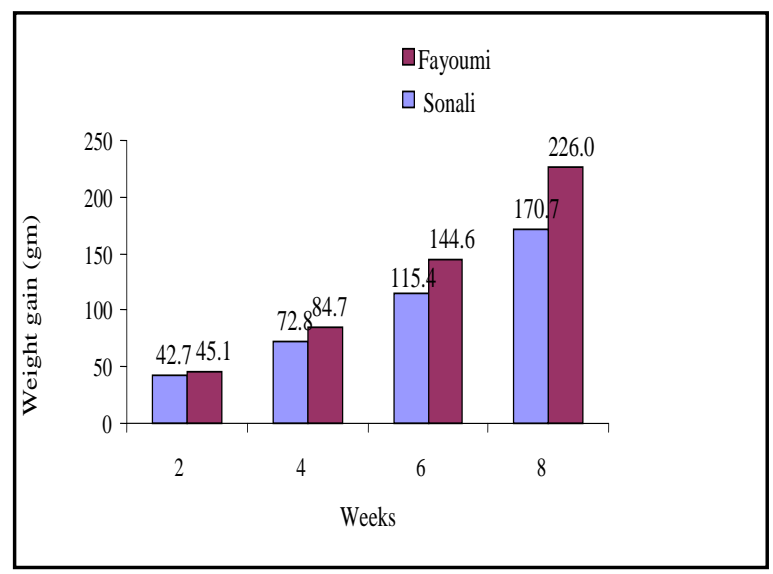

Figure 1: Weight-gain of Fayoumi and Sonali chicks up to 8th weeks of age For instance, the average weight gain of Fayoumi chicks after eight weeks was $226.0 \mathrm{gm}$ in scavenging condition, and Sonali 170.7 $\mathrm{gm}$ and the difference was statistically significant $\left(\chi^{2}\right.$ $=7.71, \mathrm{df}=1, \mathrm{p}<0.01)$.

\section{Environment effect on weight-gain}

In case of Fayoumi, the increase of weight of chicks is proportionally higher compared to the age. The Fayoumi chicks of Chittagong site gained higher weight $(285.4 \mathrm{gm})$ than that of Noakhali (171.1 gm) due to differences in the management like temperature, humidity and feeding system as well as ecological environment like land setup and population density. The weight-gain of Fayoumi chicks in two study sites has been compared and the difference between the two sites differ highly significantly $\left(\chi^{2}=28.6, \mathrm{df}=1, \mathrm{p}<0.001\right)$.

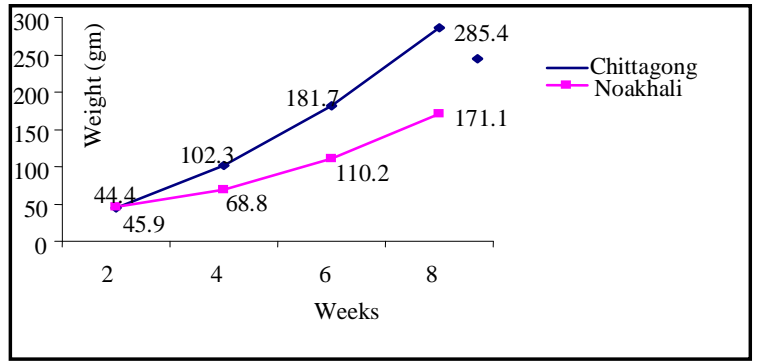

Figure 2: Weight-gain of Fayoumi chicks up to 8th weeks of age In case of Sonali chicks, the weightgain of day old to up to eight weeks aged showed the similar performance (higher $197 \mathrm{gm}$ in Chittagong and lower $139 \mathrm{gm}$ in Noakhali) like that of Fayomi as they were reared in same environment and also under the same management condition

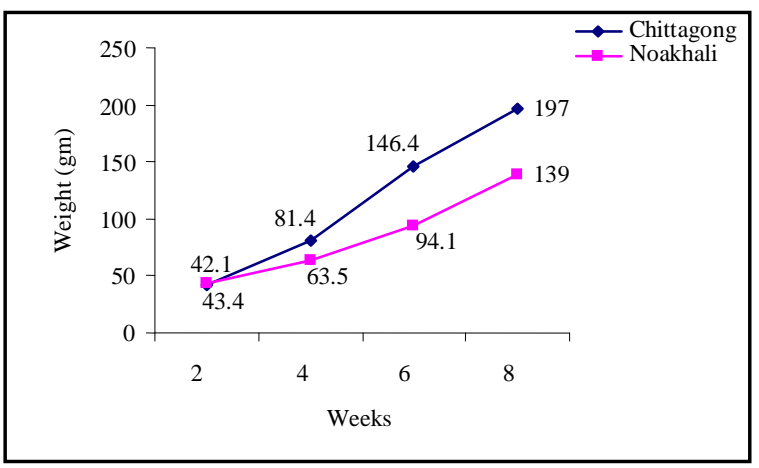

Figure 3: Weight-gain of Sonali chicks up to $8^{\text {th }}$ weeks of age

Similarly, the weight-gain of Sonali chicks at two sites was statistically significant $(\chi 2=10.01, \mathrm{df}=1$, $\mathrm{p}<0.01)$. The differences of weight gain of Sonali breed at two sites due to the different management as well as ecological setup.

\section{DISCUSSION}

Khan ${ }^{[9]}$ reported that the weight of Sonali chicks after eight weeks was $550 \mathrm{gm}$ in the semi-scavenging type of rearing method, which is too much higher than the present study. This is due to the difference in rearing system, Khan [9] did work in semiscavenging system and the present one is scavenging. The higher weight-gain of Fayoumi chicks than that of Sonali in this study, because of the former chicks has better adaptability in the environment of Bangladesh in both semi-scavenging and scavenging conditions. Weight-gain differs for two breeds because of their differences in the genetic make up as well as environment ${ }^{[8]}$. Sonali chicks are not well adapted to seek feed from surroundings because this breed has newly been developed to rear in Bangladesh. So due to lack of nutrition, this breed also suffers from several diseases, which resulted less weight-gain. Wu Cheng-kun Han You-wen found the feed efficiency with No 1 and No 2 diets for 08 and $0-10$ weeks were $2.19,2.28$ an $\mathrm{J} 2.43$, 
2.62 respectively. Statistical analyses showed: Significant difference in feed efficiency between age (P0.001), sex (P0.05) and diet (P0.001).Significant difference between age (P0.001) and diet (P0.05) in ME retention efficiency, but no significant for sex. Significant difference between age (P0.001), sex $(\mathrm{P} 0.05)$ and diet (P0.05)in protein retention efficiency ${ }^{[11]}$. Fayoumi as well as Sonali chicks of Chittagong site gained higher weight than that of Noakhali site, which is due to the differences in feeding, management and weather conditions of two areas. The temperature of Chittagong is always higher and humidity is lower than Noakhali. The higher temperature increased the metabolic rate of the chicks and lower humidity helps to protect several diseases and that help to enhance gain more weight. The variation in any flock is not only due to genetic component but environmental component is also responsible for it ${ }^{[2]}$. Genetic composition is a major factor, which governs the productive performance in various aspects of livestock. About $80 \%$ performance of poultry is dependent on gene components and $20 \%$ on environmental in exploiting genetic potential to its maximum possible extent ${ }^{[7]}$. The experiment showed that in the parameter weight gain, the Fayoumi produced the better result due to the continuous efforts for long time rearing in our environment.

\section{ACKNOWLEDGEMENT}

I am utmost delightful to Dr. Md. Farid Ahsan, Professor, Department of Zoology, University of Chittagong, Chittagong for many sorts of help provided during the project tenure. I am also grateful to SLDP2 for financing the research project from Higher Education Research Fellowship. I would like to thank DR. Mohammad Mahmudul Hassan Assistant Professor, Department of Physiology, Pharmacology and Bio-chemistry and Gous Miah , Assistant Professor, Department of Genetics and Animal Breeding of Chittagong Veterinary and Animal Sciences University for their monitoring, suggestions and inspiration.

\section{REFERENCES}

1. Ahmed Z (1997). Semi-scavenging poultry model production chin. Impact of smallholder livestock Development project in some selected
Areas of Bangladesh. Livest.Res. Rural Devel. 9(4): 23.

2. Arjona AA, Denbow DM and Weaver WD (1988). Effect of heat stress early in Life on Mortality in broilers exposed to high environmental temperatures just prior to marketing. Poultry Science. 67(2): 226-31.

3. Das GB (2005). The poultry production 1st edition. Breed description. Dhaka: Bangla Academy. Press.

4. Farooq M, Gul N, Chand N, Durrani FR, Khurshed A ( 2004). Production performance of backyard chicken under the care of women Charsadda, Pakistan. http: www.Utafoundation org/lrrd141faro141.htm. ( Access on 4/7/2006).

5. Hammond J (1947). Animal Breeding in relation to nutrition and environmental condition, Biological Review. 22: 195-213.

6. Jull MA (1952). Poultry breeding. 3rd edition. New York: John Wiley and sons. Press.

7. Katuli AM (1990). Crossbreeding as a tool for genetic improvement of chicken in suboptimum environments. Beitr Trop Landwirtsch Veterinarmed. 28 (3): 325-35.

8. Khan, A.G. 1983. Indigenous germ plasm (part I). Poultry guide. Mymensingh: Bangladesh Agricultural Univ. Press.

9. Khan, MKI (2003). Crossing Hilly with RIR and Fayoumi for the Deveopment of Layer Chicken Suitable for Semi-scavenging System with Sonali and Nera as Control. An applied research project. Chittagong: Chittagong Veterinary and Animal Sciences Univ. Press.

10. Paul DC, Huque ME and Huque MF (1995). Growth. Pattern of exotic pullets. Under farmers management. Bangladesh Journal of Scientific and Industrial Research.30(4) :15-20.

11. Wu CK and Han YW (1983). Feeding efficiency and utilization of energy and protein of broiler and different Diets. Journal of Northeast Agricultural University. 1983(2): 16571.

12. Zone-Chittagong climatic station and Maijdi Court climatic station. Temperature and humidity at Chittagong and Noakhali. 